\title{
The Relationship Between Religion, Illness and Death in Life Histories of Family Members of Children With Life-Threatening Diseases
}

\author{
Regina Szylit Bousso ${ }^{1}$ \\ Taís de Souza Serafim² \\ Maira Deguer Misko ${ }^{3}$
}

\begin{abstract}
This qualitative study aimed to get to know the relationship between the experiences of families of children with a life-threatening disease and their religion, illness and life histories. The methodological framework was based on Oral History. The data were collected through interviews and the participants were nine families from six different religions who had lived the experience of having a child with a life-threatening disease. The interviews, held with one or two family members, were transcribed, textualized and, through their analysis, the Vital Tone was elaborated, representing the moral synthesis of each narrative. Three dimensions of spirituality were related to illness and death in their life histories: a Higher Being with a healing power; Development and Maintenance of a Connection with God and Faith Encouraging Optimism. The narratives demonstrated the family's search to attribute meanings to their experiences, based on their religious beliefs.
\end{abstract}

Descriptors: Death; Religion; Child.

\footnotetext{
${ }^{1}$ Free Lecture, Faculty, Escola de Enfermagem, Universidade de São Paulo, SP, Brazil. E-mail: szylit@usp.br.

2 Nursing undergraduate student, Escola de Enfermagem, Universidade de São Paulo, Scholarship holder, Scientific Initiation Program CNPq. E-mail: tais_serafi@hotmail.com.

${ }^{3}$ RN, Doctoral Student, Programa Interunidades de Doutoramento em Enfermagem, Escola de Enfermagem and Escola de Enfermagem de Ribeirão Preto, Universidade de São Paulo, SP, Brazil. E-mail: mairadm@usp.br.
}

Corresponding Author: Regina Szylit Bousso Universidade de São Paulo. Escola de Enfermagem Av. Dr. Enéas de Carvalho Aguiar, 419 CEP: 05403-000 São Paulo, SP, Brasil E-mail: szylit@usp.br 


\title{
Histórias de vida de familiares de crianças com doenças graves: relação entre religião, doença e morte
}

Trata-se de pesquisa qualitativa com o objetivo de conhecer a relação entre as experiências de famílias de crianças que vivenciaram uma doença grave com a sua religião, doença e suas histórias de vida. O referencial metodológico usado foi a História Oral. Participaram deste estudo nove famílias de seis diferentes religiões, as quais já vivenciaram a experiência de ter uma criança gravemente doente. As entrevistas, realizadas com um ou dois membros da família da criança, foram transcritas, textualizadas e, a partir de sua análise, elaborado o Tom Vital que representa a síntese moral da narrativa. Três dimensões da religiosidade/espiritualidade foram relacionadas à doença e morte em suas histórias de vida: Ser Superior com Poder de Cura; Desenvolvimento e Manutenção de uma Conexão com Deus e a Fé Encorajando o Otimismo. As narrativas evidenciaram a busca da família por atribuir significados às experiências vivenciadas, a partir de suas crenças religiosas.

Descritores: Morte; Religião; Criança.

\section{Historias de vida de familiares de niños con enfermedades graves: relación entre religión, enfermedad y muerte}

\begin{abstract}
Se trata de una investigación cualitativa con el objetivo de conocer la relación entre las experiencias de familias, con niños que tenían una enfermedad grave, con religión, enfermedad, e historias de sus vidas. El marco metodológico usado fue la Historia Oral. Participaron de este estudio nueve familias practicantes de seis religiones diferentes, las cuales pasaron por la experiencia de tener un niño gravemente enfermo. Las entrevistas, realizadas con uno o dos miembros de la familia del niño, fueron transcritas, textualizadas y, a partir de su análisis, fue elaborado el Tono Vital que representa la síntesis moral de la narración. Tres dimensiones de la religiosidad/espiritualidad fueron relacionadas a la enfermedad y muerte en sus historias de vida: un Ser Superior con Poder de Cura; el Desarrollo y Manutención de una Conexión con Dios y la Fe Incentivando el Optimismo. Las narraciones evidenciaron la búsqueda de la familia, partiendo de sus creencias religiosas, por significados que pudiesen ser atribuidos a las experiencias de sus vivencias.
\end{abstract}

Descriptores: Muerte; Religión; Niño.

\section{Introduction}

The experience of having a life-threatening disease causes suffering and immediate attempts to attribute meanings, trying to have this situation make some sense, as this experience can often be confusing and exhausting for patients' and their families' lives $^{(1)}$.

Meanings are historically transmitted, determining the culture of a people, through which individuals develop their knowledge and activities with regard to life; as a social construction, culture permits a way of seeing the world, of experiencing it in the cognitive and emotional sense, influencing people's attitudes related to health and disease. Hence, in Western culture, religion is described as a strategy to deal with disease and its treatments $^{(2)}$.

Religious beliefs and practices serve as mediators in the health-disease process, in view of the development of cognitive schemes that could expand personal coping resources, through the feeling of control and selfesteem, favoring the attribution of meaning to stressful events $^{(3-4)}$. Religiousness allows people to understand the meanings of events as part of a broader purpose or project, through the belief that nothing happens by chance and that events in life are determined by a superior force. It also permits the belief that these events 
can lead to personal growth, with wisdom, balance and maturity ${ }^{(3)}$.

Religion is a common resource that exerts beneficial effects on adjustment to disease and important beliefs for people, which make them feel less guilty and need less information; this fact can result in reduced dependence on health professionals(5). It should be highlighted that different religions offer distinct beliefs and that, consequently, dilemmas on the disease and death experience are also perceived in peculiar ways ${ }^{(6)}$.

For parents, one of the main influences in their daily lives is when they discover that their child has a life-threatening disease. This fact provokes changes in their dreams and hopes for their children's future and, from that point onwards, these family members seek meanings and strategies to cope with such disease situations $^{(7)}$.

As religion is important for many patients, health professionals need to know the beliefs that make patients and relatives more or less willing to receive treatment. Moreover, spiritual and religious activities can be added to therapies and treatments and these facts should encourage further research in this area.

In view of the above, this research aimed to get to know the relation between the experiences of families of children with a life-threatening disease and: religion, disease and their life histories.

\section{Method}

To comply with the study goal, the qualitative approach was used. The qualitative method is recommended when little is known about a phenomenon or one intends to describe it according to the subject's viewpoint. Hence, it applies to the research question guiding the present $\operatorname{study}^{(8)}$. Considering the nature of this research, and in the belief that it is important to study phenomena from people's own perspective, in their life context, the research chose Oral History as a methodological framework, used to capture the experiences of people who were willing to talk about aspects of their lives, with the commitment to continue within their social context.

Oral History is based on the perception of the past as something that continues in the present and whose historical process is not finished; moreover, it gives meanings to testimonies and readers' social life, making them understand the historical flow and identify themselves within it. In oral history, the testimony is considered a "collaborator", which implies a relationship of affinity between interviewees and interviewers ${ }^{(9)}$.
Oral History is considered the central focus of the study and testimonies the central point of analysis. With a view to methodological rigor, the researcher focuses on the project elaboration criteria, on holding the interviews, on the process of passing oral to written text and on the result finetuned with the sense of the interview. The results are based on the expression of these interviews, as the nevralgic point of the research(9).

With regard to sample representativeness, each testimony and each interview are valuable by themselves; hence, one cannot affirm that one or some interviews "represent" the whole. The individual version of each phenomenon, however, is important and justified when considering the sum of arguments that characterize the experience as a whole, that is, for the oral history, each testimony has its own weight. Thus, one does not think that one single interview is capable of synthesizing the conception of all relatives' experience, but that the set of various interviewees' beliefs becomes significant in the attempt to understand the theme ${ }^{(9)}$.

In this research, thematic oral history was used, which seeks the interviewee's clarification or opinion on some specific subject or pre-established theme. Objectivity is direct: it addresses external, objective, factual, thematic questions, and its specific nature grants distinguished characteristics ${ }^{(9)}$.

Approval for the research project was obtained from the Research Ethics Committee at the University of São Paulo School of Nursing. Initially, the families' consent was requested by writing, through the free and informed consent term, which presented information about the research, clarifying that interviews would be recorded and guaranteeing anonymity.

To select the collaborators, a colony needs to be established. A colony is a group or community of people, who are part of the research and present characteristic behavior in a broad sense. It is defined by the preponderant traits that connect people's trajectories ${ }^{(9)}$. In this research, the colony comprised nine families from six different religions who went through the experience of having a child with a life-threatening disease. The network is a subdivision of the colony and aims to set parameters to decide which people will be interviewed $^{(9)}$.

The selection of the families included in the study was based on the criterion of having gone through the experience of having a child with a life-threatening disease from the families' own perspective. Respecting this criterion, the selected families were the researcher's acquaintances and, through these families and other people's indications, 
a network started being formed. Initial contact was made personally or by phone, when the families were invited to participate in the study and, after their consent, the interview was scheduled. At that moment, all family members were invited to participate in the interview, considering the definition that family is whom its members say it is. Hence, study participants were: nine mothers, one father and one maternal grandmother.

One spiritist, four catholic, one Baptist, one evangelical, one spiritualist and one Buddhist family were interviewed. Interviews took place in a calm and private space. The average duration was twenty minutes. Recordings were made after the interviewees' authorization and signing of the free and informed consent term.

Using a script is recommended as a fundamental tool to collect the data investigated in the thematic oral history ${ }^{(9)}$. For this study, the script consisted of three moments with distinct foci: (1) religion in the family's life history; (2) the disease experience and religion (when and how their religious beliefs affect their health and in what way) and (3) beliefs on religion and disease, and religion and death. The script was constituted by the following guiding questions: tell me how religion started to be part of your life. How did religion appear in your daily life? How do your religious beliefs affect the child's disease experiences? What does the disease mean to you? What does death mean to you?

After finishing the interviews, to proceed with the methodological procedures, the analysis was performed in three phases, as recommended ${ }^{(9)}: 1$ ) transcription - rigorous passing of the interview from tape to paper, after careful listening to the entire contents, several times, including all slips of the tongue and the interviewer's questions; 2) textualization - phase during which questions are suppressed and added to the answers, when the text is exclusively mastered by the collaborator. Here, the narrative is reorganized for clarity's sake. Then, the Vital Tone is chosen, which is a phrase that introduces the oral history because it represents the moral synthesis of the narrative or the axis that guides reading, and 3 ) transcreation - in this phase, the testimony is processed in a broader sense, inverting the order of paragraphs, removing or adding words and phrases. The atmosphere of the interview is recreated, attempting to present the reader with the world of sensations the contact provoked. The author interferes in the text, according to agreements made with the collaborator. In this procedure, the collaborator's legitimization of the interview becomes vital(9).
After reading each testimony, it was evidenced that the narratives expressed a peculiar meaning, with shared points among the histories, which could be better explored with a view to a broader understanding of their contents, as follows.

\section{Results}

In the interpretative approach adopted for this research, the researchers tried to describe each experience as it was lived, considering the perspective of the person who experienced it and the way his/her religious beliefs influence the moment of the child's disease and vice-versa.

Based on the narratives, three dimensions of religiousness/spirituality were related with disease and death in their life histories: a Higher Being with Healing Power; Development and Maintenance of a Connection with God and Faith Encouraging Optimism.

The first collaborator's statement, who was catholic, evidenced the following Vital Tone: what sustained me was my family and my faith, there is no doubt about that, I had a very premature baby at that time and I saw that who did not have a spirituality got one there, there is no atheist inside a neonatal ICU... None..

The family plays an important role during the child's hospitalization. The fact that all family members participate in the same religion made them share the same faith and this support became effective during the disease phase. The interviewees always mention the family when they report on their experiences. Traditional beliefs, taught by earlier generations, are very valuable and reminded at times of affliction.

According to the collaborator, the neonatal ICU environment is very tense in view of the diseases' severity and, considering this situation, believing in a Higher Being with power to solve problems mitigates the situation, as their fears, anguish and uncertainties are divided with Him. According to the family, belief is that God has powers over life and death.

The second narrative refers to the other catholic family, but who had not been to church for ages. The collaborator calls herself a "non-practicing catholic", and the following vital tone can be evidenced in her story: I did not go back to church to listen to the word, but because I believe that there is a higher being, who has something that you'll suddenly need when confronted with a disease moment, with something bad in your life, because I believe in something bigger... after you study and develop intellectually, we are not after the word but more after the rituals... 
After her child's cure, the collaborator reports on a phase of reflection and resignification that favored her entire family's return to religious services. The collaborator mentions that she started to value the church rituals and religious cults and believe that there exists a higher Being that supports the family in case of difficulties.

The collaborators describe the connection with God as an essential component for spirituality and not always identify it as a religious aspect. For the family, the religious institution or church formalities can make this "spiritual" connection with God more difficult. The relation or mental connection with "something bigger" is what keeps up hopes and guides the family towards the future in disease situations.

The third narrative comes from a Baptist family, and the study collaborators are the child's parents. In this narrative, the Vital Tone is as follows: religion has not become more important, because it already was, but we get even more attached when we go through difficult times, get more attached to God... you need to share your anxiety and fear with God.

The family uses praying as an important form or strategy to mitigate the suffering caused by their daughter's disease and highlights that this is common practice in their religion, used not only at times of anguish, but also for the sake of acknowledgement. Religious faith offers the family better internal emotional control, resulting in greater ability to feel comfortable in the disease's vulnerability situation. They consider that God has control over life and death. In this context, beliefs and religious practices attend to the emotional need of having expectations for the future.

The Vital Tone of narrative 4, by one mother, who served as the collaborator for a spiritualist family, was as follows: I have no religion, we are quite spiritualist at my home... My education was directed at Catholicism. I took the first communion, but my mother used to attend Spiritism a lot, and I took more and more interest when I grew up... and then, some things started happening in my life and spirituality was a way of keeping me going. The feeling of knowing that I was being helped is indescribable, by people, by friends, by their prayers.

The family highlights the importance of giving oneself to help the other in disease situations. Giving oneself to the other is mentioned as an important component of spirituality. They identify welcoming and strengthening actions by relatives and friends. The more attached to spiritualist aspects, the more the family identifies resources and keeps up its energy to continue with the stressful disease situation. Religion or religiousness cannot solve the situation instantaneously, but can help and renew energies for the family to identify resources and learn how to deal with situations. The family describes the change in its lifestyle, including health-related activities, since it started to develop its spirituality.

The next Vital Tone was evidenced in collaborator 5's narrative, who belonged to a Spiritist family: my faith became stronger after my son's disease, we definitely know that there's someone looking after us and that's comforting, someone up there, some greater strength, I think we have to know how to ask and say thank you and believe in that.

Besides establishing a personal connection in "Something bigger", one needs to have faith. Having faith in Something bigger is what helps the family to remain calmer when faced with the adversities of life including the life-threatening disease. By praying, the family establishes its connection with God or Something bigger and strengthens its faith. Praying becomes a fundamental component to deal with the adversities of the disease.

The next narrative came from a mother and grandmother in a Catholic family and evidenced, according to the collaborators, Vital Tone 6: and that's the part of religion we got attached to, I made a lot of promises, I went to Aparecida a lot and I believe, like, that we are supported, that we sometimes think that we won't bear it, but thanks God we're here....

The family considers religion as an important source of support to face the critical moments of the child's disease; because it is a very severe chronic condition, crises phases always return. The family is shocked and believes it can only cope with those moments because there is a Higher Being that comforts them and, thus, strengthens them in view of the experience. Besides, the family highlights the devotion practices that strengthen its members' beliefs. They consider that their faith is tested and needs to be proven. They make promises that represent their capacity to give themselves and their gratitude to God for the grace they were granted the cure of the disease.

Vital Tone 7 presents the narrative of a mother from a Buddhist family: he wouldn't get better, so I started to do a lot of daemoko at the hospital, it was a case of life or death and, after a lot of praying, he got better; that's when I had the real evidence, right? It served to deepen my faith, it makes you believe more in what you practice.

Like for other families, faith has always been important and the beliefs they learned are unquestionable. 
This family believes that prayers determined their son's improvement and this strengthens the family's faith. For the family, the child's improvement represents the strength of prayer and faith to revert an adverse situation. Faith encourages its members' optimism.

Based on collaborator 8's narrative, who was evangelical, the following Vital Tone was evidenced: when I heard about my daughter's suspected leukemia I did not accept it, because I believe that the Lord takes our diseases, so we cannot accept it; one verse says that disease may reach us, but that it can also leave with God's power.

This statement evidences that she does not accept her daughter's disease, as she believes in a Higher Being who is capable of healing all diseases. Hence, according to her, this Being can cure, so that the disease does not exist. Her belief rests in a Higher Being with power to solve all of her problems.

Vital Tone 9 was evidenced in the narrative of a Catholic mother: I got really scared that my daughter would die. So, what was I gonna do? I kneeled down and prayed a lot and asked: Our Lady of Aparecida, bless my daughter, get her out of this situation. My faith is so big that I manage everything I ask for.

According to her, the critical times during her daughter's hospitalization were overcome by her faith. She reports that her prayers and requests, formulated to a Higher Being, were what permitted her child's recovery.

\section{Discussion}

In a life-threatening disease situation, the family deals with suffering as possible at that specific time, as coping actions are limited by the pressure of the event, by the system of predominant beliefs and by the assessment of available coping resources(10).

Religious coping is one possible strategy to face a disease situation; the family uses religious resources to understand and deal with it. People constantly face personal or situational urgencies, in some cases, using the religious resource of prayers, promises, ascetic exercises and ritual actions, according to the different religions $^{(11)}$.

This research identified these religious resources; in some narratives, promises were mentioned, specifically in Catholicism, when families promised something in exchange for the child's cure. But the main religious resource families used in this research was prayer. Prayer plays a fundamental role to sustain the relation with the Higher Being, that is, communication with this Being happens through prayer, either to ask or thank for something ${ }^{(12)}$. Besides, prayer is also something concrete relatives can do for the child in a disease situation, generating comfort for the relatives and helping them to be emotional and physically involved with their child(13) Hence, prayer expresses a desire, a longing for something but, according to christianism, this desire becomes true if it is the Higher Being's will(14). In christianism, for example, one of the strongest manifestations of the Higher Being's presence are physical care and some socalled psychic cures, which patients themselves or other people often request in $\operatorname{prayer}^{(11)}$.

Religious search should not be understood as flight from reality, but as a future perspective when people are confronted with a life-threatening disease situation. This view helps to understand how and why religions offer symbolically effectiveresults with regard to wellbeing and self-control(15). Religion performs different functions, such as creating an identity that links people, capturing new energy in the fight for survival and strengthening cultural resistance that, by itself, also strengthens the search for religion as a solution, according to the research participants' narratives ${ }^{(16)}$

Various studies $(3-4,7,10-11,13,15)$ have demonstrated the influence of religious beliefs on the construction of meanings in stressful events. These also offer a better understading of people's need to construct and reconstruct these meanings and realities, attempting to overcome the suffering imposed by the disease experience.

The relation between religious symbols and social life is established in the course of the disease and death events, in which individuals borrow, confront and reinterpret the symbols in the light of certain goals and interests $^{(17)}$. The range of religions included in the study was restricted and, therefore, these results cannot be generalized.

\section{Conclusion}

This research discusses the importance of religious beliefs and the development of spirituality as a form of support in disease and death situations and a form of coping with them as well as possible, as they increase faith and hopes of cure and offer tranquility to face adversities. They are important to nursing to the extent that they open up possibilities to understand and accept that other people are beings permeated by beliefs based on their respective religions.

Families carry out spiritual and secular actions to guarantee the best professional care for their children 
and attempt to influence God's will in their own and their family's favor. This research contributes to the understanding of different religions' forms of seeing the world and cure projects, incorporated into the experiences of the sick children and their families.

It is important to highlight that the use of the narrative focused on the subject's perspective on health and disease, aimed at offering new information and perspectives instead of definitive conclusions.

Religion is considered a significant factor in the belief system related to health and disease, strongly influencing disease-related perceptions, attitudes and beliefs. Health professionals need to acknowledge the multiple perceptions related to disease and death, shared by different religions, so that they are truly able to understand, get access to and attend to the spiritual spheres of care, integrating mind, body and spirituality.

The theme religions and its relation with disease and death from a family perspective deserves further research and different research strategies. Other studies are needed to evidence how and the extent to which these relations are relevant for clinical practice.

\section{References}

1. McLeod DL, Wright LM. Living the As-Yet unanswered: spiritual care practices in family systems nursing. J Fam Nurs 2008; 14(1):118-41.

2. Helman CG. Culture, health and illness. London: Arnold; 2001.

3. Dull VT, Skokan LA. A cognitive model of religion's influence on health. J Soc Issues 1995; 51:49-64.

4. Siegel K, Anderman SJ, Schrismshaw EW. Religion and coping with health-related stress. Psychol Health 2001; 16:631-53.

5. MacConville $U$. Mapping religion and spirituality in an Irish palliative care setting. Omega 2006; 53(1-2):137-52.

6. Clarfield AM, Gordon M, Markwell H, Alibhai SM. Ethical issues in end-of-life geriatric care: the approach of three monotheistic religions-Judaism, Catholicism, and Islam. J Am Geriatric Soc 2003; 51(8): 1149-54.

7. Raingruber B, Milstein J. Searching for circles of meaning and using spiritual experiences to help parents of infants with lifethreatening illness cope. J Holist Nurs 2007; 25(1):39-49.

8. Field PA, Morse JM. Nursing research: the application of qualitative approaches. London: Croom Helm; 1985.

9. Meihy JCSB. Manual de história oral. São Paulo: Loyola; 1998.
10. Faria JB, Seidl EMF. Religiosidade e enfrentamento em contexto de saúde e doença: revisão de literatura. Psicol: Reflex Crít 2005; 18(3):381-9.

11. Paiva GJ. Religião, enfrentamento e cura: perspectivas psicológicas. Estudos Psicol 2007; 24(1):99-104.

12. Rehm RS. Religious faith in mexican-american families dealing with chronic childhood illness. J Nurs Scholarship 1999; 31(1):33-8.

13. Schneider MA, Mannell RC. Beacon in the storm: an exploration of the spirituality and faith of parents whose the children have cancer. Issues Comprehensive Pediatr Nurs 2006; 29:3-24.

14. Gaarder J, Hellern V, Notaker H. O livro das religiões. São Paulo: Companhia das Letras; 2005.

15. Aquino VV, Zago MMF. O significado das crenças religiosas para um grupo de pacientes oncológicos em reabilitação. Rev Latino-am Enfermagem 2007; 15(1):42-7.

16. Geertz C. A interpretação das culturas. Rio de Janeiro: Livros Técnicos e Científicos; 1989.

17. Rabelo MC. Religião e cura: algumas reflexões sobre a experiência religiosa das classes populares urbanas. Cad Saúde Pública 1993; 9(3):316-25. 